\title{
TELEMATIC EDUCATION: A REALITY IN POST-BASIC NURSING EDUCATION
}

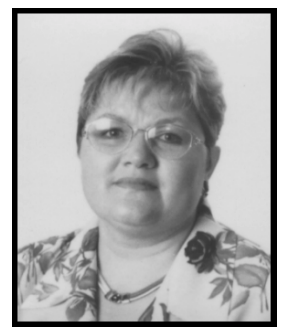

\author{
Salomé M Meyer \\ Lecturer: Department of Nursing Science, University of Pretoria
}

\begin{abstract}
No institution is immune to the impact of technological change. The introduction of cable television and satellite broadcasting has resulted in an increase in employing the technology in question for educational purposes. Computers and communication technologies are merging globally, and technology such as Telematic Education is being used in the best possible way by the University of Pretoria to support its service delivery mechanisms.
\end{abstract}

Telematic Education refers to a comprehensive system of flexible learning. It includes all modes of education, as well as low and high technological methods. Although nurses/lecturers have been confronted with the fast development of technology for many years, it has been in clinical practice mostly. Professional nurses need to develop professionally in non-clinical specialities as well. Continued education by means of a distant education method will serve as an academic solution to professional nurses in the rural areas of South Africa.

Lecturers who teach by means of telematic education are required to be skilled, self-confident, and should also be flexible. The twenty-first century will indeed see many changes, with lecturers, students and preceptors joined together in dialogue to question, demonstrate, and participate actively in the learning process. All of this will happen without students having to set foot in a classroom.

\section{OPSOMMING}

Geen instansie is immuun teen tegnologiese veranderinge nie. Die bekendstelling van satelliet en kabeltelevisie het gelei tot ' $n$ vermeerderde gebruik van tegnologie vir onderwyskundige doeleindes. Daar is ' $n$ samesmelting van rekenaar en kommunikasie tegnologie wêreldwyd en tegnologie soos Telematiese Onderwys word deur die Universiteit van Pretoria gebruik op die mees geskikte wyse om hul dienslewerings sisteme te ondersteun.

Telematiese onderrig verwys na 'n omvattende sisteem van fleksi-leer. Dit sluit alle modi van onderwys, sowel as lae en hoë tegnologiese metodes in. Verpleegkundiges/dosente word al jare deur tegnologie gekonfronteer, maar hoofsaaklik in die kliniese praktyk. Verpleegkundiges/dosente moet egter ook tegnologie as deel van hul professionele ontwikkeling in nie-kliniese areas sien. Voortgesette onderwys by wyse van afstandsonderrig dien as ' $n$ oplossing vir verpleegkundiges in die landelike gebiede van Suid-Afrika.

Telematiese onderrig vereis van dosente om kundig en plooibaar te wees, asook die medium met selfvertroue te gebruik. Die een-en-twintigste eeu sal verseker baie veranderinge meebring, soos dosente, studente en preseptore saamkom in debatvoering ten einde te bevraagteken, demonstreer en aktief deelneem in die leerproses. Dit kan alles plaasvind sonder dat die dosent of die student fisies in die klaskamer is.

\section{INTRODUCTION}

Television broadcasting has been a solution to the educational needs of geographically widespread campuses of vast countries such as Australia and Canada, and also to student populations of universities that are widespread. The introduction of cable television and satellite broadcasting has increased the use of this technology for educational purposes (Laurillard, 1993:113). One-way broadcasts of lecture content, however, are not very effective.

Many nurses in rural areas of South Africa have been denied the opportunity to further their profes- 
sional skills and knowledge as they do not have access to Universities and most of them are full time employees. By bringing the classroom to the student by means of televised post-basic programmes/courses these nurses are now able to fulfill their professional dreams and continue with lifelong learning, as the profession requires.

To be of any value to a student, television education must be interactive in nature. This implies that student and lecturer must be able to communicate while a lecture is being broadcast live by means of an interactive television lecture. Telematic Education (TE), which is not the mere use of the television set as a teaching tool/aid, comes to mind.

\section{PURPOSE OF THE ARTICLE}

The purpose of this article is to give an indication on what is happening at the University of Pretoria regarding TE as well as discuss some aspects of TE. These aspects include: the nature of TE, the approach of the nursing educator during a TE broadcast, the necessity of active involvement on the part of the student, as well as some benefits and limitations of the use of TE.

\section{UNIVERSITY OF PRETORIA (UP)}

No institution is immune to the impact of technological change. Because they have failed to respond with a dynamic and flexible strategy, countless organisations and industries have been swept away by the "waves of creative destruction" associated with technological innovation. Organisations can only benefit from exploiting technological change if it is regarded and managed as a strategic resource. The Rector of the University of Pretoria, Prof. Johan van Zyl initiated the development of a formal Technology Plan for the University, when he took office in 1997. The aim of the Plan is to enhance the University's competitive position by ensuring that technology is used in the best possible way to support its service delivery mechanisms.

The deployment of the Technology Plan has already borne fruit. The establishment of the Unit for Telematic Teaching and the subsequent Virtual Campus initiative are direct benefits of the Plan. Computers and communication technologies are merging globally, and in order to accommodate this trend, UP will change its organisational structure to manage these integrated technologies (Anonymous, 2000:19).

\section{TELEMATIC EDUCATION (TE)}

In order to understand what TE is all about, it is important to know the meaning of flexible learning. Dr Tom Brown of the Telematic Education Department of the University of Pretoria defines it as: "... a philosophy of education that refers to a learner centred approach to teaching and learning". According to Brown (1999) this learner-centred approach allows flexibility in terms of aspects such as:

- $\quad$ Exit and entry to academic programs

- $\quad$ Portability and accreditation

- $\quad$ Education/delivery modes

- $\quad$ Time, place and pace of study

- $\quad$ Styles and strategies of learning

TE refers to a comprehensive system of flexible learning. It emphasises the use of technology to enhance the teaching and learning environment. TE is mainly delivered over distance. It is important to know that paper-based teaching/learning is also regarded to be technology. TE includes all modes of education, as well as low and high technological methods, such as:

$\begin{array}{ll}\text { - } & \text { Face-to-face (contact) } \\ \text { - } & \text { Felephone } \\ \text { - } & \text { E-mail } \\ \text { - } & \text { Interactive television } \\ \text { - } & \text { Paper-based } \\ \text { - } & \text { Video conferencing } \\ \text { - } & \text { Multimedia } \\ & \text { Web-based }\end{array}$

TE, if managed properly, has the ability to address the learning needs of all learners concerned, be they dependent or independent, groups or individuals. The more dependent the learner, the lower the technology employed and vice versa. The dependent learner will be more directed by the lecturer whereas the independent student who is capable of self-study, will be able to employ the higher technological learning facilities.

According to Devaney (1996:15), interactive telecommunication is: "... a linking of two locations over fibre optic or dedicated T-1 telephone lines. Participants are able to see and hear each other simultaneously. In the educational setting, all the dynamics of the traditional classroom are preserved, regardless of the distance separating the locations". This is the ideal situation. Unfortunately available technology and finances do not always lend itself towards such a perfect situation. 


\section{INTERACTION}

To communicate during broadcasts, is a whole different ball game to having a normal conversation. Only one person can speak at a time. Due to the distance, sound/voice signals have to travel, it takes two or three seconds before it is heard on the other side and before the next person can speak and be heard. This may lead to confusion, and even waste time, as people have to repeat questions and answers. This might also lead to students not wanting to participate in the on-line discussions.

A possible solution, but only to a certain extent, is to structure a typical teaching session in two parts. During the first part of the lecture, the lecturer presents the content, i.e. the passing on of knowledge to the students. The second part of the lecture can then be in the form of a discussion/question-andanswer session, with much interaction between the lecturer and the students (Jameson, Hanlon, Buckton, \& Hobsley, 1995:114). This may be of value if the students were well informed beforehand of the content of the lecture and thus come prepared to class.

The need for students to have back-up videos/copies of broadcasts originates from some students who are unable to attend the broadcast sessions due to employer or other demands. The possibility of a technical failure preventing students at one site to participate in a session cannot be ignored (Jameson et al. 1995:45). Copying of videos is very simple, while editing and distributing is an expensive exercise.

\section{THE NURSING EDUCATION SITUA- TION}

Nurses/lecturers have been confronted with the fast development of technology for many years, but mostly in clinical practice. The fact that the world is becoming smaller every day through the advancement of communication and information technology is a reality.

Telematic education (TE) is employed in nursing education (NE) for post-basic programs. Post-basic, (i.e. non-clinical) programs imply that people who are registered with the South African Nursing Council (SANC) as professional nurses who continue to further their skills and knowledge regarding certain specialisations in the profession.
Continued education for post-basic nurses by means of a distance education method will serve as an academic solution to professional nurses in the rural areas of South Africa. According to Tagg \& Arreola (1996:154): "Distance education programs involve the use of television, in conjunction with other forms of telecommunications technology, to deliver instruction to students at a remote site. Distance education programs should not be confused with instructional television (ITV), which, more often than not, involves simply the rebroadcast of lectures that require only passive reception by the student".

Jack Yensen (1996:213), defines this method of teaching as telenursing, and is of the opinion that the two key dimensions are distance and electronic mediation. This reminds one once again that television has made the world a smaller place and that it has an impact on society in every aspect. Television has also become a very important education tool and influences the way in which we teach our students, as well as in what we teach (Tagg \& Arreola, 1996:154).

A few questions come to mind. Firstly: is it a successful teaching method? Secondly: are telematic broadcasts sufficient and effective? According to Penney, Gibbons \& Bushy (1996:28) there is a lack of data regarding the healthcare professional's experience with distance education.

\section{THE LECTURER}

Lecturers who teach by means of telematic education are required to be skilled, self-confident, understand the uniqueness of rural students and, also be flexible. They should take the concepts of adult learning into consideration and respect the authority of experience that many students bring to the classroom. To enable the lecturer to deliver a high standard of education during TE, it is important that the technological backup is of a high quality. For this a qualified and skilled technician must be available during broadcasts (Ranstrom, 1997:5).

The technology to support TE has been developing at a very fast pace, and lecturers qualified to teach by means of this method are in short supply. Lecturers who do not have the experience to teach by means of this method, need sufficient training; not technical courses, but training on how to adjust their current method of teaching as well as their teaching aids to the telematic medium (Yeaworth, 1996:150). The face value of the instruction should 
also be taken into consideration, i.e. the technical quality of the learning material that is created whether print, audio or video. The use of technology influences educational innovation.

Lecturers of the Department of Nursing Science at the University of Pretoria were requested to complete questionnaires for a research project done in 1998 by the author, and they had the following comments on TE (Meyer, 1998:10-11):

\section{Benefits}

- Many students can be reached at once without them having to come to class.

- Valuable video clips can be used as part of the broadcast.

- Students can be more responsible for their own learning.

- Adult teaching principles can be employed.

\section{Limitations}

- Movement of the lecturer is limited.

- Students are hesitant to ask questions.

- It is not possible to build a relationship with students.

- It is not possible to have a proper discussion such as a case study.

- Students do not come to class prepared.

- Students study by means of rote learning and try to memorise all the televised content.

- No active participation by students, only passive listening.

\section{Concerns}

- Spend more time on preparation of lectures as no interaction from students is anticipated.

- Have a bigger workload.

- Not possible to stimulate the student's creativity, cognitive thinking, insight, etc.

\section{THE STUDENT}

Active participation by the student is essential to the process of learning. Many students learn best by doing. Active participation by the student allows the lecturer to assess the student's understanding of complex content. If students do not get the opportunity to apply what they have learned, they will not be able to recall it later (Yucha, 1996:2). An old Chinese proverb emphasises this: "Tell me ... I'll forget. Show me ... I'll remember. Involve me ... I'll understand."

The ergonomic factors that will enhance student participation and involvement during TE are therefore of the essence. There should be a telephone line open in the event of a technical fault occurring during broadcasts, which will enable the students to still have contact with the lecturer. The telephone should be in reach of all students in the room. If only one microphone is used, it should be within reaching distance of all students.

A very good suggestion is to have a fax machine available in the broadcast studio. This will enable the lecturer to receive questions when telephone lines are occupied or very busy, with more than one venue linked to the studio. When transmitting television broadcasts to remote sites, two-way audio and video transmission seems to be of a higher quality than the common one-way television programming (Tangalanos, McGee \& Bigbee, 1997:44).

Students of the Department of Nursing Science of the University of Pretoria who participated in the same research project as the lecturers in 1998, were asked to complete a separate questionnaire, and had the following comments on TE:

\section{Benefits}

- It enables the students to work and study at the same time even if situated far from the University.

- An opportunity to further their education.

- Facilities close to home may serve as motivation to start studying again.

- Can phone lecturer after class.

\section{Limitations}

- Lecturer going too fast.

- Telephone out of reach or not working.

- Too little time allocated to ask questions.

- Not enough personal contact with the lecturers.

- Very limited access to an academic library.

\section{Other concerns}

- There is a need for more copies of videos (even to buy).

- Broadcasts cannot always be attended due to personal circumstances. 


\section{Positives}

- Lecture content of a very high quality.

- Lecturer's knowledge of a very high standard.

\section{Negatives}

- Get bored looking at the "talking head".

\section{SUGGESTIONS}

- Students should be briefed/oriented on the method of teaching before their first experience of TE.

- Study guides/workbooks should be developed in such a manner that it contains the necessary information for students to prepare for the following broadcast. (Information such as the specific modules/units of content that will be discussed.)

- Lecturers should be trained to utilise a TE session to the full, as well as to facilitate optimal learning.

- Contact times where the students can have personal contact with the lecturer should be planned once or twice a semester.

\section{CLOSING REMARKS}

The twenty-first century will see many changes, the first of which will be the end of the extensive emphasis on classroom teaching. Some programs will be presented without students ever having to set foot in a classroom. Lecturers, students, and preceptors will join in dialogue to question, demonstrate, and participate actively in the learning process. Nursing will develop a 'world view' in the process.

"Remember, the information revolution will continue to roll on - with or without you. So, get on board and begin changing" (Simpson, 1997:27).

\section{SOURCES}

Anonymous 1999: Technology will determine competitiveness. Die Tukkie, 7(1).

Brown, T 1999: Telematic Education at the University of Pretoria. MS PowerPoint slide show. (http:// www.up.ac.za/academic/education/didactics/modules/ ivx880/course/library.htm\#show).

Devaney, SW 1996: Spotlight on: Health Education via Interactive Television. Nurse Educator, 21(4):15-16. Jameson, DG; Hanlon, PO; Buckton, S \& Hobsley, M 1995: Broadband Telemedicine: Teaching on the Infor- mation Superhighway. Journal of Telemedicine and Telecare, 1:111-116.

Laurillard, D 1993: Rethinking university teaching: A framework for the effective use of educational technology. Routledge: London and New York.

Meyer, SM 1998: Telematic Education in the Department of the Medical Faculty of the University of Pretoria: A Descriptive Study. Paper of Essay for the Honours degree BCur I et A in Advanced Nursing Education. Penney, NE; Gibbons, MS \& Busby, A 1996: Partners in Distance Learning: Project Outreach. Journal of Nursing Administration, 26(7/8):27-36.

Ranstrom, C 1997: Restructuring Interactive Television: An Educator's Perspective. Nurse Educator, 22(1):5. Tagg, PI \& Areola, RA 1996: Earning a Master of Science in Nursing Through Distance Education. Journal of Professional Nursing, 12(3):154-158.

Tangalanos, EG; McGee, R \& Bigbee, AW 1997: Use of the New Media for Medical Education. Journal of Telemedicine and Telecare, (3):40-47.

Yeaworth, RC 1996: Consortia Arrangements and Educational Telecommunication. Journal of Professional Nursing, 12(3):147-153.

Yensen, J 1996: Telenursing, Virtual Nursing and Beyond. Computers in Nursing, 14(4):213-214.

Yucha, CB 1996: Interactive Distance Education: Improvisation Helps Bridge the Gap. Journal of Bio-Communication, 23(1):2-7. 